\title{
The social construction of Afro-descendant rights in Colombia
}

\author{
Esther Ojulari
}

Afro-descendant people make up around 30 per cent of the population of Latin America and the Caribbean, some 150 million people (IACHR 2011). In a context of mestizaje and the myth of racial democracy, Afro-descendant rights were not institutionalised in many Latin American states until the end of the 20th century. This reflected an invisibility at the international level where a specific normative framework on Afro-descendant rights did not begin to emerge until the beginning of the 21st century. Through multicultural citizenship reforms in the 1980s and 1990s several Latin American states recognised rights for their Afro-descendant populations; however, these tended to be subsumed into the existing indigenous rights framework, thus neglecting the specific situations of Afro-descendants.

Using theoretical concepts from the sociology of human rights and critical race theory (CRT) this chapter poses some key issues for analysing the institutionalisation of Afro-descendant rights in Latin America and, in particular, in Colombia. It draws on literature from the social constructionist perspective on human rights, which demonstrates how rights emerge in particular historical and political contexts and are institutionalised through processes of negotiation between states and civil society, often influenced by powerful economic and political interests (see Waters 1996; Freeman 2002; Morris 2006; Samson and Short 2006; Short 2007; Miller 2010; Haynes et al. 2011).

Critical race theory (CRT) places the issues of race and racism at the centre of analyses. With roots in critical legal studies, CRT critiqued US civil rights laws for failing to lead to significant change and rather serving the wider political and international interests of the State and white elite (see Bell 1995; Ladson-Billings and Tate IV 1995; Ladson-Billings 1998; Taylor et al, 2009; Delgado and Stefancic 2012). The chapter combines social constructionist theories with CRT concepts of structural racism, 'interest convergence' and 
'model minorities' to explore the discourses, interests and processes which influenced the institutionalisation of Afro-descendant rights in Colombia.

\section{Afro-descendant rights in context}

\section{Historic context: invisibilising racism}

CRT views racism as structural, institutional and endemic to society in the United States (US), underpinning and informing all social relations (Taylor 2009; Delgado and Stefancic 2012). As part of post-independence, nationbuilding projects, many countries in Latin America promoted mestizo national identities that supposedly celebrated the racial and ethnic diversity of the nations (Andrews 2004). States espoused an idea of 'racial democracy' asserting that, in contrast to the Jim Crow segregation laws of the US, Latin American societies were characterised by harmonious race relations and racial equality (Gates Jr. 2012; Telles 2004; Cottrol 2001). However, the ideology of mestizaje has served to assimilate Afro-descendants and indigenous peoples denying their histories, cultures and contributions to their nations (de Friedman and Arocha 1995). Rather than removing racial categories, the ideology of mestizaje actually reconstructs categories re-establishing a basis for racism (Wade 2004). Both mestizaje and the myth of racial democracy were extremely influential in shaping racial discourse throughout the region, denying the existence of racism and creating barriers for Afro-descendant movements to make claims for racial justice (Safa 1998; Htun 2004; Reichmann 1999; Ng'weno 2012; Morrison 2012).

It has since been argued that racial democracy is a 'myth' as racism and racial inequality are very real problems throughout Latin America (Alberti and Araujo 2006). A wealth of literature shows that Afro-descendants are disproportionately represented among the most marginalised groups in the region and while often equated to class, the socio-economic inequalities they face are underpinned by structural discrimination and racism (Hasenbalg 1996; Safa 1998; Sanchez and Bryan 2003; Htun 2004; Murillo 2011; Inter-American Commission on Human Rights 2011; Leighton 2012; UNDP 2012; Telles 2014).

\section{Political context - a space for model minorities?}

The CRT concepts of 'model minorities' and 'differential racialisation' explore the ways in which different minority groups are racialised by mainstream society. For example, the stereotyping of certain minority groups in the US as 'successful' in education and employment based on hard work, often downplays experiences of racism and exclusion and is used to legitimise the low achievement and inequality of other groups, blaming them for their own lack of success (Delgado and Stefancic, 2012).

In Latin America, outside of the Brazilian context, the ideology of mestizaje was based on a binary between white European and indigenous peoples, 
promoting romantic celebration of an indigenous past, while excluding Afro-descendants (Paschel 2010; Wade 1997). This 'indigenous inclusion, black exclusion' (Hooker 2005) translated to a lack of policies and legislation recognising the existence and rights of Afro-descendants.

Towards the end of the 20th century, as indigenous rights were institutionalised at the international level, many countries in Latin America underwent multicultural citizenship reforms adopting new constitutions which recognised, the multicultural nature of their societies. Reflecting the language of ILO Convention 169 concerning Indigenous and Tribal Peoples in Independent Countries (1989), they included rights to territory, culture, language, identity, political participation and education for ethnic groups (Sieder 1998).

This ethnic rights discourse, however, provided limited space for inclusion of Afro-descendants, who had traditionally been imagined along racial rather than cultural/ethnic lines (Wade 1997). Only some of the States that adopted new constitutions included rights for their Afro-descendant populations, and these were much more limited in scope than those provided for indigenous peoples (Hooker 2005).

The Colombian 1991 Constitution contains several provisions on indigenous peoples' rights but only one provisional article (PA55) on Afrodescendants, which led to the adoption of Law 70 of 1993: 'In Recognition of the Right of Black Colombians to Collectively Own and Occupy their Ancestral Lands.' The differences in scope of rights for the two groups are stark. For example, constitutional law provides a quota system to guarantee two seats in the Senate (Constitution 1991, article 171) and one seat in the House of Representatives for indigenous peoples (law 649 of 2001, article 1) who officially make up 3.4 per cent of the population (DANE 2005; 2010). Conversely, Afro-descendants who make up 10.5 per cent $^{1}$ of the population are guaranteed just two seats in the House of Representatives (Law 70, article 66; Law 649, article 1).

The model minority concept is useful here for analysing the differential racialisation of Afro-descendants and indigenous peoples. Popular comparisons between the two groups often emphasise how indigenous movements have been more organised and articulated in their demands, while fractions and tensions within the Afro-descendant movement are often cited as reasons for their continued lack of success. Such distinctions fail to unpick the historical and continued differential discourses and treatment that have fed into these differences.

1 It is important to note that due to issues of self-identification and capacity in census taking, these figures are often considered to be underestimates of the true population size. 


\section{Framing rights claims for inclusion}

The language used in the construction of rights is essential to analyse how rights are institutionalised and implemented in practice. O'Byrne asserts that through the study of the language of rights sociologists can understand the institutional frameworks within which meanings are negotiated and practices formalised' $(2012,832)$.

The 'indigenous inclusion, black exclusion' paradigm has meant that Afrodescendant communities that have gained recognition and rights tend to be those that articulate their claims within the indigenous rights framework around territory and culture (Hooker 2005). ${ }^{2}$ Some Afro-Colombian civil society organisations point out that presenting a case based on racial discrimination can have little audience, while emphasising cultural difference is more effective (Wade 2009; Paschel 2010).

Thus, the political space that opened up through the multicultural citizenship reform made room for those groups who articulated their claims within the 'ethnic rights' language. Cultural and identity rights had long been an important demand of the Afro-Colombian movement (Pisano 2014). However, Restrepo (2013) argues that the lead up to the drafting of the Constitution involved an 'ethnicisation' of Afro-descendant claims in which organisations, mainly from the rural, Pacific region of the country had to emphasise demands for cultural, territorial and identity rights. During the actual drafting of the Constitution no Afro-descendant organisations were included in the Constitutional Committee and their interests were therefore represented by two indigenous participants and a number of anthropologists who also tended to take an ethnic rights approach (Wade 2009; Paschel 2010).

Reflecting this, PA55 and consequently Law 70 of 1993 apply to comunidades negras (black communities) which are defined as:

... the group of families of Afro-Colombian descent who possesses its own culture, shares a common history and has its own traditions and customs within a rural-urban setting and which reveals and preserves a consciousness of identity that distinguishes it from other ethnic groups (Ley 70, 1993, article 2, para.5).

Thus, the law that provides rights to collective land titles, autonomy, political participation and 'ethno-education' (culturally relevant education) applied only to those Afro-descendants considered distinct, traditional ethno/cultural groups, mainly in the pacific region. This raised questions of its applicability to Afro-descendants outside of this context (Restrepo and Rojas 2012).

2 For example, Garífuna, communities in Central America have been successful in gaining collective titles to land through multicultural provisions in their country's constitutions (Thorne 2004; Anderson 2007). 


\section{Interest convergence}

The social constructivist perspective of human rights demonstrates that political authorities institutionalise rights only when they perceive them to be in their own interests and when they do not threaten existing power structures (Waters 1996; Freeman 2002; and Miller 2010). Rights should therefore not be assumed to be automatically beneficial to the rights holders. Similarly, the CRT concept of 'interest convergence' argues that legal liberalism cannot be considered as objective, neutral or 'colour-blind.' Therefore civil rights laws and court decisions, such as rulings on desegregation or affirmative action, cannot lead to real racial justice, but rather serve wider political and economic State interests (see Bell 1995; Ladson-Billings and Tate IV 1995; Ladson-Billings 1998; Dudziak 2009; Delgado and Stefancic 2012).

In Colombia, the framing of Afro-descendant rights as rural, Pacific 'ethnic group' rights effectively enabled the State to evade obligations towards the rights of Afro-descendants who do not fit the criteria. Law 70 does extend beyond the Pacific region, for example, establishing political participation mechanisms for Black Communities from throughout the country (article 45). Further, several Constitutional Court rulings have expanded the scope of specific areas of the law. ${ }^{3}$ However, there are still many barriers to proper implementation.

In the area of education, for example, my initial research in urban contexts demonstrates how ethno-education has been concentrated in majority Afrodescendant communities who more closely resemble a distinct ethnic group, excluding those Afro-descendants that live in more multicultural contexts. In the areas of collective land titles and participation, Afro-descendant communities face barriers realising these rights in part because their status as an 'ethnic group' had been questioned (Ng'weno 2012). ${ }^{4}$

After generations of neglect of Afro-Colombian ancestral territories in the Pacific region by the State, they are now the object of State and private palm oil cultivation, mining and other large-scale development projects (Murillo 2011). In the context of these neo-liberal interests, it may have suited the State to concentrate the Afro-descendant rights framework on these regions (Wade 2009). The Afro-descendant rights framework establishes mechanisms for free, prior, informed consent in development projects in the region. From an 'interest convergence' perspective this can be seen as enabling the State

3 See for example Constitutional Court rulings T-422/96 which applied education rights to black communities in the city of Santa Marta on the Caribbean Coast; and C-169/01 which expands Law 169 on political participation to include Raízal communities from San Andrés y Providencia in the definition of 'black communities'.

4 See Constitutional Court ruling T-823/12 in which a black community brought a case against the Departmental Government of Valle de Cauca for failing to fulfil their right to participation in accordance with article 45 of Law 70. 
to legitimise development activities within the multiculturalist framework, effectively reconciling its neo-liberal interests with its multicultural rights obligations.

From a CRT perspective, the ethnic rights focus 'de-racialises' (Paschel 2010) Afro-descendant rights. Law 70 contains only one mention of racism (article 33) and does not specify 'any concrete proposal, sanctioning of racist acts, or clear policies' to address racism (Paschel 2010). Therefore the framework effectively denies the role that structural racism plays in the human rights violations and exclusion of Afro-Colombians.

\section{Conclusion: using international human rights to gain domestic recognition}

The consolidation of a rights framework for Afro-descendants in Colombia represents a significant advancement towards social justice, which would not have been possible without the tireless lobbying and activism by Afrodescendant civil society. However, the social constructionist and CRT frameworks enable a critical analysis of the institutionalisation of these rights, demonstrating their limitations. The restriction to 'ethnic rights' meant Afrodescendants would have to demonstrate they fit the category of an 'ethnic group' to be subjects of these rights. Further, de-racialising the rights effectively perpetuated the myth of racial democracy by denying the role that racism plays in the human rights violations of all Afro-Colombians, whether in the rural Pacific or other contexts.

Rights become institutionalised at the domestic level through a combination of State interests, pressure from social movements and the consolidation of frameworks at the international or regional levels. At the time of the adoption of the Colombian Constitution, there were no specific international or regional mechanisms on the rights of Afro-descendants. However, since the 2001 Third UN World Conference against Racism, a normative framework on the rights of Afro-descendant has begun to emerge. ${ }^{5}$ This has expanded Afro-descendant rights from focus on traditional ethnic groups with territorial and cultural

5 This is contained in: several paragraphs in the World Conference outcome document, the Durban Declaration and Programme of Action (Declaration paras. 13-14; 32 35; and 103; and Programme of Action paras. 4-14); General Recommendation 34 on racial discrimination against people of African descent of the Committee on the Elimination of Racial Discrimination (CERD); specific mention in the Inter-American Convention against Racial Discrimination (preamble) as well as an increasing number of observations and recommendations from the CERD, the UN Working Group of Experts on People of African Descent and the Inter-American Commission's Rapporteur on the Rights of Persons of African Descent and against Racial Discrimination. 
claims, to wider racial justice issues including racism in the media, racial profiling by security forces and structural discrimination.

These norms, which were largely made possible due to the activism by Latin American Afro-descendant civil society (Htun 2004; Lennox 2009), have in turn opened up new spaces for claims for racial justice at the domestic level. In this new context, anti-racism has become an increasing part of rights claims by civil society and, in 2011, Colombia adopted Law 1482 against racism and discrimination. Social media in Colombia is now abuzz with discussions on racism, linking it to wider issues of socio-economic inequality, cultural identity, territory and autonomy. This growing discourse and awareness is essential for ensuring that Afro-descendant communities can access and use legal mechanisms to make claims both for their cultural rights as ethnic groups and for racial equality by denouncing structural and institutional racism.

\section{Bibliography}

Alberti, V., and A. Araujo Pereira (2006) 'Racial discrimination in Brazil: interviews with leaders of the black movement', in International Oral History Conference. Vol. 14. (Sydney: IOHA).

Andrews, G. R. (2004) Afro-Latin America, 1800-2000 (Oxford: Oxford University Press).

Bell, D. (1995) 'Racial realism', in K. Crenshaw, N. Gotanda, G. Peller and K. Thomas (eds.), Critical Race Theory: The Key Writings That Formed the Movement (New York: The New Press), pp. 302-12.

Constitución Política de Colombia, 1991.

Cottrol, R. J. (2001) 'The Long, Lingering Shadow: Law, Liberalism, and Cultures of Hierarchy and Identity in the Americas', Tulane Law Review 76, pp. 11-80.

Crenshaw, K., N. Gotanda, G. Peller and K. Thomas (eds.) (1995) Critical Race Theory: The Key Writings That Formed the Movement (New York: The New Press).

DANE (2005) 'Censo General 2005’ (Bogotá: Departamento Administrativo Nacional de Estadísticas (DANE)).

- (2010) 'La Visibilización Estadística de Los Grupos Étnicos Colombianos'. (Bogotá: Departamento Administrativo Nacional de Estadísticas (DANE)), http://www.dane.gov.co/files/censo2005/etnia/sys/visibilidad_ estadistica_etnicos.pdf.

De Friedemann, N. S. and J. Arocha (1995) 'Colombia', in P. Pérez Surday and J. Stubbs (eds.), No Longer Invisible: Afro-Latin Americans Today (London: Minority Rights Group International), pp. 47-76. 
Delgado, R. and J. Stefancic (2012) Critical Race Theory: An Introduction. (2nd edn., New York and London: New York University Press).

Dudziak, M. L. (2009) 'Desegregation as a Cold War imperative', in E. Taylor, D. Gillborn and G. Ladson-Billings (eds.), Foundations of Critical Race Theory in Education (New York and London: Routledge), pp. 85-95.

Durban Declaration and Programme of Action (adopted at the World Conference Against Racism, Racial Discrimination, Xenophobia and Related Violence, 8 September 2001, Endorsed 15 May 2002) UNGA $56 / 266$.

Freeman, M. (2002) Human Rights: An Interdisciplinary Approach, Key Concepts (Malden, MA: Polity).

Gates, Jr., H. (2011) Black in Latin America (New York and London: New York University Press).

Hasenbalg, C. (1996) 'Racial inequalities in Brazil and throughout Latin America: timid responses to disguised Racism', in E. Jelin and E. Hersheberg (eds.), Constructing Democracy: Human Rights, Citizenship, and Society in Latin America (Boulder, CO: Westview Press).

Hooker, J. (2005) 'Indigenous inclusion, black exclusion: race, ethnicity and multicultural citizenship in Latin America', Journal of Latin American Studies 37 (2), pp. 285-310.

Htun, M. (2004) 'From racial democracy to affirmative action: changing state policy on race in Brazil', Latin American Research Review 39 (1), pp. 60-89.

Hylton, K. (2012) 'Talk the talk, walk the walk: defining critical race theory in research', Race Ethnicity and Education 15 (1), pp. 23-41.

Hynes, P., M. Lamb, D. Short and M. Waites (eds.) (2011) Sociology and Human Rights: New Engagements. (Abingdon: Routledge).

Inter-American Commission on Human Rights (2011) 'The situation of people of African descent in the Americas', OEA/Ser.L/V/II, Doc. 62 (Washington DC: Organization of American States).

Ladson-Billings, G. and W. F. Tate IV (1995) 'Toward a critical race theory of education', Teachers College Record 97 (1), pp. 47-68.

Ladson-Billings, G. (1998) 'Just what is critical race theory and what's it doing in a nice field like education?', International Journal of Qualitative Studies in Education 11 (1), pp 7-24.

Leighton, K. (2012) The Scandal of Inequality in Latin America and the Caribbean (London: Christian Aid).

Lennox, C. (2009) 'Reviewing Durban: examining the outputs and review of the 2001 World Conference Against Racism', Netherlands Quarterly of Human Rights 27 (2), pp. 209-13. 
Ley 70 de 1993 (27 de Agosto): Por La Cual Se Desarrolla El Artículo Transitorio 55 de La Constitución Politica, Congreso de La República de Colombia.

Ley 649 de 2001 (marzo 27): Por La Cual Se Reglamenta El Artículo 176 de La Constitución Política de Colombia. El Congreso de La República de Colombia.

Ley 1482 de 2011 (noviembre 30): Por Medio de La Cual Se Modifica El Código Penal Y Se Establecen Otras Disposiciones. El Congreso de La República de Colombia. n.d.

Miller, H. (2010) 'From 'rights-based' to 'rights-framed' approaches: a social constructionist view of human rights practice', The International Journal of Human Rights 14 (6), pp. 915-31.

Morris, L. (ed.) (2006) Rights: Sociological Perspectives (Abingdon: Routledge).

Morrison, J. (2012) 'Social movements in Latin America: the power of regional and national networks', in K. Dixon and J. Burdick (eds.), Comparative Perspectives on Afro-Latin America (Gainesville, FL: University Press of Florida), pp. 243-63.

Murillo, P. (2011) 'El Tercer Laboratorio de La Paz Y La Población Afrocolombiana', Acción Social.

Ng'weno, B. (2012) 'Beyond citizenship as we know it: race and ethnicity in Afro-Colombian struggles for citizenship equality', in K. Dixon and J. Burdick (eds.), Comparative Perspectives on Afro-Latin America (Gainesville, FL: University Press of Florida), pp. 156-75.

O’Byrne, D. (2012) 'On the sociology of human rights: theorising the language-structure of rights', Sociology 46 (5), pp. 829-43.

Omi, M. and H. Winant (1994) Racial Formation in the United States: From the 1960s to the 1990s (Abingdon: Routledge).

Paschel, T. S. (2010) 'The right to difference: explaining Colombia's shift from color blindness to the law of black communities', American Journal of Sociology 116 (3), pp. 729-69.

Pisano, P. (2014) 'Movilidad Social E Identidad 'negra' En La Segunda Mitad Del Siglo Xx: Social mobility and 'black' identity in the second half of the 20th century', Anuario Colombiano de Historia Social Y de La Cultura 41 (1), pp. 179-99.

Reichmann, R. (1999) Race in Contemporary Brazil: From Indifference to Inequality (University Park, PA: The Pennsylvania State University Press).

Restrepo, E. (2013) Etnización de La Negritud: La Invención de Las "Comunidades Negras" Como Grupo Etnico En Colombia. Genealogias de La Negritud (Popayán: Editorial Universidad de Cauca). 
Restrepo, E. and A. Rojas (2012) 'Políticas Currículares En Tiempos de Multiculturalismo: Proyectos Educativos De/para Afrodescendientes En Colombia', Currículo Sem Fronteiras 12 (1), pp. 157-73.

Safa, H. (1998) 'Race and national identity in the Americas', Latin American Perspectives 25 (3), pp. 3-12.

Samson, D. and D. Short (2006) 'Sociology of indigenous peoples rights', in L. Morris (ed.), Rights: Sociological Perspectives (Abingdon: Routledge).

Sanchez, M. and M. Bryan (2003) Macro Study: Afro-Descendants, Discrimination and Economic Exclusion in Latin America (London: Minority Rights Group International).

Sieder, R. (2002) Multiculturalism in Latin America: Indigenous Rights, Diversity and Democracy (Basingstoke: Palgrave Macmillan).

Short, D. (2007) "The social construction of indigenous "native title" land rights in Australia', Current Sociology 55 (6), pp. 857-76.

Taylor, E., D. Gillborn and G. Ladson-Billings (eds.) (2009) Foundations of Critical Race Theory in Education (New York: Routledge).

Telles, E. (2004) Race in Another America: The Significance of Skin Color in Brazil (Princeton, NJ: Princeton University Press).

- (2014) Pigmentocracies: Ethnicity, Race, and Color in Latin America (Chapel Hill, NC: University of North Carolina Press).

UN Committee on the Elimination of Racial Discrimination (2011), General Recommendation No 34 on Racial Discrimination against People of African Descent, UN Doc. CERD/C/GC/34. (30 September 2011).

UNDP (2012) Análisis de La Situación Socioeconómica de La Población Afroperuana Y de La Población Afrocostarricense Y Su Comparación Con La Situación de Las Poblaciones Afrocolombiana Y Afroecuatoriana. (Panamá: United Nations Development Programme).

Wade, P. (2009) 'Defining Blackness in Colombia', Journal de La Société Des Américanistes 95 (1), pp. 165-84.

- (2004) 'Images of Latin American Mestizaje and the politics of comparison', Bulletin of Latin American Research 23 (3), pp. 355-66.

- (1997) Race and Ethnicity in Latin America (London \& Chicago: Pluto Press).

Waters, M. (1996) 'Human rights and universalisation of interests: towards a social constructionist approach', Sociology 30 (3), pp. 593-600. 